реальних об'єктів (телевізор, магнітофон, телефон, факс, комп'ютер, принтер, модем, копір) та інформаційних технологій (аудіо- та відеозапис, електронна пошта, ЗМІ, Інтернет) формуються вміння самостійно шукати, аналізувати та відбирати необхідну інформацію, організовувати, перетворювати, зберігати та передавати іiі.

5. Комунікативна компетентність - знання необхідних мовних ресурсів (володіння тезаурисним запасом географічної науки), засобів взаємодії з людьми і подіями безпосередньо й опосередковано; навички роботи в групі, володіння різними соціальними ролями в колективі.

6. Соціально-трудова компетентність - це володіння знанням і досвідом у громадянськосуспільній діяльності (виконання ролі громадянина, наглядача, представника, виборця тощо), в соціально-трудовій галузі (права споживача, покупця, клієнта, виробника), в сфері родинних відносин і обов'язків, у питаннях економіки та права, у професійному самовизначенні. До змісту цієї компетенції віднесено, наприклад, уміння аналізувати ситуацію на ринку праці, діяти відповідно до особистої й суспільної користі, володіти етикою трудових і громадянських взаємовідносин. Учень оволодіває мінімально необхідними для життя в сучасному суспільстві навичками соціальної активності та функціональної грамотності.

7. Компетентність особистісного вдосконалення спрямована на засвоєння засобів фізичного, духовного та інтелектуального саморозвитку, емоційну саморегуляцію та самопідтримання. Реальним об'єктом в цьому випадку є сам учень, який оволодіває способами діяльності у власних інтересах та можливостях, що виявляється в його безперервному самопізнанні, розвитку необхідних сучасній людині особистісних якостей, формуванні психологічної грамотності, культури мислення і поведінки.

Географічна компетентність учнів як форма практичного засвоєння результатів пізнання економічної діяльності, яка здобута завдяки навчанню й орієнтована на самостійну участь особистості в навчально-пізнавальному процесі, а також на успішне ії включення в трудову діяльність дозволяє розглядати ііі як систему: 1) знань, умінь і навичок розуміння законів географічної науки; 2) географічних знань, умінь $i$ навичок розуміння й інтерпретачї природних явищ і відношень між ними; 3) географічних знань, умінь і навичок роботи $з$ географічними поняттями.

Подана структура географічної компетентності в перспективі вимагає детального розгляду педагогічної категорії «географічні знання» в загальноосвітній системі в процесі навчання учнів географії та основ соціальної географії.

\title{
Література
}

1. Равен Дж. Педагогическое тестирование : Проблемы, заблуждения, перспективы / Джон Равен ; [пер. с англ.]. - [2-е изд., испр.]. - М. : «Когито-Центр», 2001. - 142 с. 2. Хуторской А. В. Ключевые компетенции как компонент личностно-ориентированной парадигмы / А. В. Хуторской // Народное образование. - 2003. - № 2. - С. 58-64.

\section{ФОРМУВАННЯ ОСНОВ ЕКОЛОГІЧНОЇ КУЛЬТУРИ УЧНІВ СЕРЕДНІХ КЛАСІВ У ПРОЦЕСІ ВИВЧЕННЯ ПРИРОДОЗНАВСТВА}

Хроленко М. В. Формування основ екологічної культури учнів середніх класів у процесі вивчення природознавства.

Стаття присвячена актуальній проблемі формування екологічної культури учнів 5-го класу засобами дидактичної гри. У статті розкрито значення екологічних дидактичних ігор у формуванні екокультури особистості, розроблено критерії добору навчального екологічного матеріалу, запропоновано типологію таких ігор та наведені приклади їх використання.

Ключові слова: екологічне виховання, екологічна культура, ігрова діяльність, екологічна дидактична гра.

Хроленко М. В. Формирование основ экологической культуры учеников средних классов в процессе изучения природоведения.

Статья посвящена актуальной проблеме формирования экологической культуры учащихся 5-го класса средствами дидактической игры. В статье раскрыто значение экологических 
дидактических игр в формировании экокультуры личности, разработаны критерии отбора учебного экологического материала, предложена типология таких игр и приведены примеры их использования.

Ключевые слова: экологическое воспитание, экологическая культура, игровая деятельность, экологическая дидактическая игра.

Chrolenko M. V. Forming the basis of ecological culture of middle classes in the study of nature science.

The article is dedicated to the actual problem of formation of ecological culture of the pupils of the 5th forms by special pedagogical gaming. In the article disclosed the importance of the ecological educational games in the formation of ecological culture of personality, developed criteria for the selection of educational material, proposed typology of games, and examples of their use.

Key words: environmental education, ecological culture of the person, game activity, ecological didactic game.

Актуальність дослідження зумовлена необхідністю розв'язання проблем, пов'язаних із загостренням відносин суспільства і природи. Без ефективної екологічної освіти та виховання виникнення i загострення екологічних проблем буде явищем постійним, оскільки першопричина їх появи - не розвиток техніки та технології, а антропоцентрична свідомість.

Екологічна освіта і виховання $є$ об'єктом дослідження багатьох науковців. Основні підходи, принципи, мету та педагогічні умови ефективності екологічної освіти і виховання розкрито у працях С. Алексєєва, С. Глазачева, А. Захлєбного, І. Звєрева, І. Суравегіної. Питання теорії і практики формування відповідального ставлення до природи відображені у працях О. Вознюка, Н. Дагбаєвої, О. Коваленко, В. Савельєвої, А. Сидельковського. В останні десятиріччя практичним аспектам екологічного виховання приділяли увагу вітчизняняні дослідники-педагоги, зокрема, В. Бродвій, Г. Ковальчук, В. Комендар, Є. Писарчук, Г. Пустовіт, Н. Пустовіт, Л. Шаповал та ін. [2, с. 45].

У Національній доктрині розвитку освіти України у XXI столітті, Основних напрямах державної політики України в галузі охорони довкілля, Концепції екологічної освіти в Україні та інших документах визначено, що результатом процесу екологічного виховання $\epsilon$ формування екологічної культури особистості.

У багатьох дослідженнях 3 проблем екологічного виховання наголошується на ефективності активних методів формування екологічної культури. Серед них - насичена екологічним змістом ігрова діяльність.

Психологічні основи ігрової діяльності, витоки й історичне значення людської гри обгрунтовані Е. Берном, Д. Ельконіним, Л. Виготським, О. Леонтьєвим. На розвивальному і виховному значенні гри наголошували Ю. Азаров, Л. Артемова, Н. Болдирєв, М. Відерман, Є. Гельфан. Проблемі і можливості застосування ігрової діяльності як методу інтенсивного навчання приділяли увагу В. Анісімова, А. Артемова, А. Вербицький, А. Дахтлер, Д. Ельконін та інші $[4$, с. 4$]$.

Отже, на сучасному етапі досліджено загальні тенденції формування основ екологічної культури учнів засобами дидактичної гри у процесі вивчення природознавства. Цій проблемі присвячено спеціальні практичні розробки і рекомендації, проте без відповідного наукового обгрунтування застосування екологічних дидактичних ігор може мати лише епізодичний характер, а риси екологічної культури школярів не можуть розвиватись гармонійно. Тому ряд аспектів у цьому напрямку вимагає поглибленого вивчення, теоретичного осмислення, пошуку нових продуктивних шляхів, умов і засобів активізації цього процесу, що дозволяють зробити його більш успішним, цілеспрямованим та ефективним.

Meта cmammi - теоретично обгрунтувати значення дидактичних ігор у формуванні екологічної культури учнів 5-го класу, навести приклади застосування таких ігор у процесі вивчення природознавства.

Під поняттям «екологічна культура» розуміємо сукупність екологічних знань, переконань, умінь і навичок, які гармонізують взаємозв'язки між людиною і природою. Вона $є$ невід'ємним складником духовного світу людини, який становить екологічно зорієнтовану свідомість і 
поведінку, в основі яких лежать гуманістичні ціннісні орієнтації та установки стосовно до природи.

Екологічна культура розглядається як частина загальної культури особистості. Тому мова може йти не про її наявність чи відсутність, а про рівень ії сформованості. Оскільки екологічна культура формується та розвивається упродовж всього життя людини, то стосовно учнів 5-го класу коректніше вести мову про основи екологічної культури.

У структурі екологічної культури ми визначаємо компоненти:

1) інтелектуальний - це потреба у глибоких і міцних знаннях екологічного змісту, вибір певної екологічної позиції (погляди, ідеї);

2) операційно-мотиваційний - це інтереси, потреби, установки, мотиви, ціннісні орієнтації у ставленні до природного довкілля;

3) емоційно-вольовий - це емоції, переживання, почуття та настрої, що виникають в учнів у зв'язку із сприйняттям та оцінкіою природних, соціальних і духовних явищ, які мають екологічну значущість;

4) діяльнісно-поведінковий - це програма дій щодо реалізації попередніх компонентів, що визначає рівень сформованості екологічної культури особистості.

Отже, екологічна культура $є$ складним структурним утворенням, тому важливо враховувати всі ії компоненти. Недооцінка будь-якого з них істотно знижує практичні та педагогічні ефекти формування цього феномену.

Серед активних методів формування екокультури школярів середніх класів найбільш ефективним, на нашу думку, є насичена екологічним змістом ігрова діяльність. Саме така діяльність дозволяє уникнути надмірного навантаження учнів, підвищує якість засвоєння навчального матеріалу, сприяє усвідомленню міжпредметних зв'язків, формує навички колективного спілкування тощо. 3-поміж усієї різноманітності ігор саме дидактичні ігри мають широкі можливості щодо формування досліджуваної якості особистості. Доцільність застосування екологічних дидактичних ігор у 5-му класі зумовлюється характерними віковими особливостями учнів: вразливістю до сторонніх впливів, непосидючістю, швидкою стомлюваністю, відставанням морального розвитку від розумового тощо [3, с. 236].

Цінність дидактичних ігор полягає ще і в тому, що в них перед дітьми ставляться дидактичні завдання, для розв'язання яких потрібна зосередженість, довільна увага, розумове зусилля, вміння осмислити правила, послідовність дій, перебороти труднощі. Ігри сприяють розвитку в дітей відчуттів і сприймання, формуванню уявлень, засвоєнню знань, надають змогу навчити дітей використовувати раціональні способи розв'язання певних розумових і практичних завдань [1, с. 137].

Нині є чимало науково-педагогічних розробок, які присвячені застосуванню дидактичних ігор 3 метою екологічного виховання учнів 5-го класу. Однак, у практиці екологічного виховання школярів застосовуються переважно однотипні ігри: вікторини, ребуси, кросворди, які майже не торкаються емоційно-вольової та діяльнісно-поведінкової сфер особистості і спрямовані на формування інтелектуального компонента екологічної культури.

Дидактичну гру ми розглядаємо як засіб розвитку пізнавальної активності учнів, спрямований на формування потреби в знаннях, активного інтересу, удосконалення пізнавальних умінь і навичок.

Критеріями добору навчального матеріалу, сприятливого для застосування екологічних ігор, $€$ :

- достатній обсяг обов'язкової та додаткової інформації, доступної для розуміння учнями 5-8 класів;

- можливість встановлення міжпредметних зв'язків;

- спрямованість пізнавальних інтересів певної вікової групи школярів;

- наявність місцевих, краєзнавчих матеріалів;

- можливість встановлення зв'язків між змістом навчального матеріалу та побутовою галуззю людської життедіяльності [4, с. 10].

Нами було розроблено типологію ігор, що відповідає підходу до гри як до поліфункціонального явища. Типологія враховує: навчально-виховну мету, навчальний зміст, ігрову форму, наявність додаткових засобів, час та місце проведення ігор.

Ми визначили такі види дидактичних ігор: 
-сюжетно-рольові - сюжет є формою інтелектуальної діяльності; найбільш показовою в цьому плані є активність уяви, яка надає своєрідність цій формі діяльності;

- izpu-вправи - це своєрідні вправи творчого характеру, які допомагають школярам краще сприймати і запам'ятати навчальний матеріал;

- ігри-драматизації - створюються за готовим сюжетом з літературного твору;

- ігри- конструювання - копіюють професійну діяльність дорослих.

Було розроблено та втілено в практику авторські ігри, які сприяють формуванню саме емоційно-вольового i поведінково-діяльнісного компонентів, забезпечують розвиток переживань, почуттів, інтересів, переконань, ціннісних орієнтацій, сприяють виявам щоденної природоохоронної поведінки школярів.

Зокрема, у курсі природознавства для учнів 5-го класу під час вивчення розділу «Всесвіт як середовище життя людини» рекомендуємо проводити різноманітні дидактичні ігри. Їх мета навчити дітей розрізняти небесні тіла, розвивати уявлення про Галактику, Всесвіт, планети Сонячної системи та природні явища, виховувати гуманне ставлення до природи та середовища життя людини. Зокрема, значні можливості у формуванні мотиваційно-ціннісного компонента екологічної культури мають ігри-метаморфози, оскільки передбачають уявне перевтілення школярів в об'єкти довкілля, внаслідок чого останні постають рівнозначними суб'єктами спілкування. Наприклад, у процесі вивчення тем: «Небесні тіла. Всесвіт», «Сонце», «Сонячна система» можна застосовувати такі ігри-метаморфози:

- Місяць, Сонце, Земля;

- упізнай мене;

- інсценування природного явища;

- хімічне забруднення водойм;

- забруднення водних об'єктів.

Під час гри «Сонце, Місяць, Земля» учні об'єднуються в команди. Від кожної команди виходять на середину класу по три учні, які виконують роль Сонця, Землі і Місяця. Ведучий дає завдання показати, як змінюються пори року, чому змінюеться день і ніч, припливи i відпливи. Учні наочно демонструють, як відбуваються ці явища, обертаючись один навколо одного відповідно до виконуваної ролі.

Мета гри «Впізнай мене» - узагальнити знання учнів з теми «Небесні тіла. Всесвіт». Клас ділиться на дві команди. Один гравець 3 кожної команди описує якусь планету, але не називають іiі. Інші відгадують, яку планету мав на увазі представник з команди.

Гру-метаморфозу «Інсценування природного явища» можна використовувати для поглиблення знань учнів про природні явища. Клас ділиться на дві команди. Кожна команда придумує загадку про певне природне явище (наприклад, дощ, сніг, град, туман), а інша повинна відгадати та зобразити це явище.

Під час гри «Хімічне забруднення водойм» учні імітують екологічну проблему. А у грі «Забруднення водних об’єктів» школярам пропонується відгадати, яку екологічну проблему порушують люди.

Серед ігор-вправ найпопулярнішими виявилися такі: «Вибери правильну дорогу» та «Відгадай пору року». Основна мета гри «Вибери правильну дорогу» - уточнити знання учнів про взаємозв'язок людини 3 природою на основі конкретних правил поведінки в природному середовищі. Під час гри учні повинні були визначити, якою стежкою вони пройдуть і пояснити свій вибір (наприклад, пропонуються три стежки: якщо піти першою - можна потоптати конвалії, якщо другою - наступити на мурашник, посередині третьої - горить багаття).

Мета гри «Відгадай пору року» - розвивати вміння школярів відгадувати загадки, співвідносити словесний образ із зображенням на малюнку, уточнювати знання про сезонні явища природи. Під час гри на парті перед кожним учнем лежать малюнки - відгадки. Пропонуються загадки, а учні шукають і піднімають малюнок - відгадку та пояснюють свій вибір.

Під час вивчення теми «Місяць - природний супутник Землі» доцільно провести грудраматизацію «Ми на Місяці». Школярам пропонується початок фантастичної казки про подорож до супутника Землі, наприклад: уявіть собі, що ви прилетіли на Місяць і опинись в цьому місці абсолютно випадково після того, як загадали бажання. Учні мають продовжити казку, застосувавши знання з цієї теми. 
Отже, у процесі застосування екологічних дидактичних ігор учні закріплюють та поглиблюють знання про природні процеси та явища, виявляють ініціативність, креативність, творчість. Дидактична гра в усіх своїх видах виконує різні функції, але домінує - мотиваційна та виховна, саме 3 цих позицій слід оцінювати ії переваги порівняно 3 іншими методами навчання. Для того, щоб дидактична гра ефективно впливала на формування екологічної культури учнів, необхідно дотримуватись вищеописаних методичних вимог, застосовувати ігри систематично та в певній послідовності. Перспективи подальших досліджень вбачаємо у вивченні питання про методичне забезпечення ігрового навчання різних вікових груп учнів.

\section{Література}

1. Алексюк А.М. Загальні методи навчання в школі / А. М. Алексюк. - К. : Академвидав, 2004 352 с. 2. Крисак А. Екологічне виховання молоді / А. Крисак // Біологія. - 2009. - № 16.- С. 44-50. 3. Павелків Р. В. Загальна психологія / Р. В. Павелків. - К.: Кондор, 2009. - 576 с. 4. Пруцакова О. Л. Формування основ екологічної культури учнів 5-8-х класів засобами дидактичної гри: автореф. дис. на здобуття наук. ступеня канд. пед. наук : спец. 13.00.07 «Теорія і методика виховання» / О. Л. Пруцакова. K., 2002. -20 c.

УДК 378.094.016:51

Ольга Чашечникова, Тетяна Панченко

\section{РОЗВИТОК НЕСТАНДАРТНОГО МИСЛЕННЯ ШКОЛЯРІВ ЧЕРЕЗ РОЗВ'ЯЗУВАННЯ ФУНКЦІОНАЛЬНИХ РІВНЯНЬ}

Чашечникова О. С., Панченко Т. І. Розвиток нестандартного мислення школярів через розв'язування функціональних рівнянь.

Стаття присвячена теоретико-методичній проблемі формування та розвитку творчого мислення учнів в умовах диференційованого навчання математики. На основі аналізу розв'язування функціональних рівнянь продемонстровано можливості впливу їх виконання на розвиток нестандартного мислення учнів.

Ключові слова: функціональне рівняння, творче мислення, нестандартне мислення.

Чашечникова О.С., Панченко Т.И. Развитие нестандартного мышления школьников посредствам решения функциональных уравнений.

Статья посвящена теоретико-методической проблеме формирования и развития творческого мышления учащихся в условиях дифференцированного обучения математике. На основе анализа решения функциональных уравнений продемонстрированы возможности влияния их выполнения на развитие нестандартного мышления учащихся.

Ключевые слова: функциональное уравнение, творческое, нестандартное мышление.

Chashechnikova O. S., Panchenko T. I. Development of innovative thinking of students through the solution of functional equations.

The article is devoted to the theoretical and methodological bases for formation and development of the creative thinking in differentiated teaching of mathematics. On the basis of functional equations solution analysis, the possibilities of their performance influence on the development of learners' innovative thinking are demonstrated.

Key words: functional equation, creative thinking, original thinking.

Творчість у навчанні математики як обов'язковий компонент передбачає оперування якісною інтелектуальною базою із предмета. Інтелектуальною базою називаємо систему знань та умінь учня (студента) з математики та його досвід іiї використання.

Збагачення інтелектуальної бази з математики, ії вдосконалення не зменшує прагнення людини до пізнання, а стає стимулом до творчості. Тому необхідно максимально використовувати можливості навчання математики для розвитку творчої особистості школярів (студентів) незалежно від обраного ними профілю навчання (майбутньої спеціальності).

Досліджуючи проблеми розвитку творчого мислення учнів в умовах профільного навчання математики [6; 7], ми обгрунтували, що розвинене творче мислення учнів сприяє підвищенню 